This is the peer-reviewed version of the paper:

Pantić, T., Milanović, I., Lukić, M., Grbović Novaković, J., Kurko, S., Biliškov, N., Milošević Govedarović, S., 2020. The influence of mechanical milling parameters on hydrogen desorption from Mgh2-Wo3 composites. International Journal of Hydrogen Energy 45, 7901-7911. https://doi.org/10.1016/j.ijhydene.2019.07.167

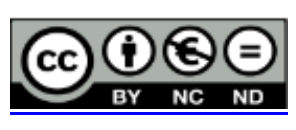

This work is licensed under the Attribution-NonCommercial-NoDerivatives 4.0 International (CC BY-NC-ND 4.0) 



\section{THE INFLUENCE OF MECHANICAL MILLING PARAMETERS ON HYDROGEN DESORPTION FROM MgH $\mathrm{MO}_{3}$ COMPOSITES}

Tijana Pantić ${ }^{1}$, Igor Milanović ${ }^{1}$, Miodrag Lukić ${ }^{2}$, Jasmina Grbović Novaković ${ }^{2}$, Sandra Kurko $^{1}$, Nikola Biliškov ${ }^{3}$, Sanja Milošević Govedarović ${ }^{1 a}$

${ }^{1}$ University of Belgrade, Vinča Institute of Nuclear Sciences, Centre of Excellence for Hydrogen and Renewable Energy - CONVINCE, Mike Petrovića Alasa 12-14, 11000 Belgrade, Serbia

${ }^{2}$ Institute of Technical Sciences of the Serbian Academy of Sciences and Arts, Knez Mihailova 35/IV, 11000 Belgrade, Serbia

${ }^{3}$ Ruđer Bošković Institute, Bijenička cesta 54, 10000 Zagreb, Croatia

Abstract

The influence of different milling conditions obtained using two high-energy mills on hydrogen desorption from $\mathrm{MgH}_{2}-\mathrm{WO}_{3}$ composites was investigated. The morphology, particle and crystallite size were studied as a function of milling speed, vial's volume, and ball-to-powder ratio. The vial's fill level, the number, and type of milling balls and additive's content kept constant. Changes in morphology and microstructure were correlated to desorption properties of materials. Higher milling speed reduced particle size but, there is no significant crystallite size reduction. On the other hand, additive distribution is similar regardless of the energy input. It has been noticed that different energy input on milling blend, which is the result of combined effects of above-mentioned factors, reflects on desorption temperature but not on the kinetics of desorption. In fact, desorption mechanism changes from 2D to 3D growth with constant nucleation rate, despite obtained changes in microstructure or chemical composition of the material.

Keywords: $\mathrm{MgH}_{2}, \mathrm{WO}_{3}$, composites, mechanical milling, desorption properties, kinetic analysis

\section{Introduction}

One of the most popular methods used in the synthesis of nanostructured and amorphous materials is mechanical milling which represents the way toward green chemistry. Mechanical milling attracts the attention due to economic price, simple handling and no need for a solvent. During mechanical milling a material undergoes to the reduction of grain size, increase in number of grain boundaries and change of surface area [1-3]. As a complex process, mechanochemical synthesis involves optimization of a numerous parameters such as: type of mill (high-energy and low-energy mills), properties of milling container (material, size and shape), milling speed, type and size of milling balls, milling time, ball-to-powder

\footnotetext{
a Sanja Milošević Govedarović, University of Belgrade, Vinča Institute of Nuclear Sciences, Centre of Excellence for Hydrogen and Renewable Energy-CONVINCE, Mike Petrovića Alasa 12-14, 11000 Belgrade, Serbia, sanjam@ vinca.rs
} 
weight ratio (BPR), vial's fill level, temperature and atmosphere (air, nitrogen, argon, etc.) that have an impact on the final product [4]. Among them, milling speed, milling time and BPR (that is an energy input) play an important role on the efficiency of the milling process. Nevertheless, one has to be aware of the fact that various difficulties can arise during milling such as: contamination of the sample by the material of the milling tools (the most common contamination is with Fe and WC [5]), increase of the temperature of the vial, and in some cases the balls could be pinned to the walls of the vial making no impact force on the powder [6]. The BPR ratio is proved to be one of the most important variables during mechanical milling. Different BPR ranging from 1:1 [7,8] up to 240:1 has been used [9], although the ratio 10:1 is used in the most of the experiments [10-12]. It is expected that higher BPR ratio will increase the rate of particle size reduction rate $[6,13,14]$. However, one should be aware of the fact that high BPR in combination with prolonged milling time leads to cold welding of particles. It also leads to pronounced contamination with Fe caused by the collision of milling balls and vial walls, as we have mentioned.

Mechanical milling under diverse conditions (different type of mills [15-17], BPR [18-20], different milling atmospheres [21-23]) is widely used as a method to improve sorption kinetics of various hydrides [24-28] and mostly magnesium hydride $\mathrm{MgH}_{2}$ [29-33]. Regarding $\mathrm{MgH}_{2}$, the most common way to improve sorption kinetics is mechanical milling with the addition of transition metals - TM (Nb, V, Ti, Mn, Fe, Co, Ni, Cu, Zn) [34-37] or transition metal oxides - TMO $\left(\mathrm{Nb}_{2} \mathrm{O}_{5}, \mathrm{Cr}_{2} \mathrm{O}_{3}, \mathrm{~V}_{2} \mathrm{O}_{5}, \mathrm{VO}_{2}, \mathrm{TiO}_{2}, \mathrm{WO}_{3}, \mathrm{MoO}_{2}, \mathrm{Mn}_{2} \mathrm{O}_{3}\right)$ [3843]. Zaluska et al. reported that some of the effects of milling that improve kinetics are particle and grain size reduction, as well as the increase of quantity of defects [44]. Mechanical milling of the $\mathrm{MgH}_{2}$ with TM or TMO introduces structural defects, increases specific surface area and the number of active sorption sites. Additives can act as efficient milling reagent for $\mathrm{MgH}_{2}$ and can improve the hydrogen sorption by reducing particle size and desorption temperature [32]. The TM or TMO chemisorbs hydrogen and transfers it to the $\mathrm{Mg}$ matrix $[45,46]$. The interface between the $\mathrm{Mg}$ and $\mathrm{TM}$ acts as an active nucleation site for the hydride phase $[47,48]$.

This work deals with the influence of different milling conditions and different additive concentrations on the desorption properties of $\mathrm{MgH}_{2}-\mathrm{WO}_{3}$ milling blends. Due to the fact that tungsten is a multivalent metal, it is expected that the addition of the oxide $\mathrm{WO}_{3}$ might produce an improvement in hydrogen sorption, similar to those obtained by $\mathrm{VO}_{2}$ or $\mathrm{TiO}_{2}$ addition $[43,49]$.

\section{Material and methods}

$\mathrm{MgH}_{2}-\mathrm{WO}_{3}$ composites were prepared by mechanical milling of the as-received $\mathrm{MgH}_{2}$ powder (Alfa Aesar, 98\% purity) with the addition of 5, 10 and 15 wt.\% of $\mathrm{WO}_{3}$ (Koch Light Labs, $99.9 \%$ purity). $10 \mathrm{wt} . \%$ is commonly used quantities for additives in magnesiumbased composites although amounts can go up to $50 \mathrm{wt} \%[26,34,37,40,41,46]$. With the addition of $10 \mathrm{wt} . \%$ of additive the capacity of $\mathrm{MgH}_{2}$ remains above satisfactory $5 \mathrm{wt} . \%$ of hydrogen. Mechanical milling was performed in two mills SPEX 5100 Mixer Mill and SPEX 8000M Mixer Mill using different conditions as shown in Table 1. Generally, the vial in SPEX mills follows a complex motion that combines back-and-forth swings with short lateral 
movements. In both cases, one milling ball (diameter $8 \mathrm{~mm}$ ) was used. The vials were loaded with powders and balls up to $40 \%$ of the volume in order to leave enough space for efficient milling [50]. As shown in Table 1, the milling vials differ in size: vial from SPEX 8000M is about 3 times higher than one from SPEX 5100 (comparing inner heights). Therefore, the distance between impacts is about 3 times longer in SPEX 8000M which is affecting overall energy input of milling. Samples were milled for 30 minutes under the inert atmosphere of argon. The samples were labelled as shown in Table 2.

Table 1. The parameters of milling process

\begin{tabular}{ccccc}
\hline Mixer Mill & RPM* & Vial volume & Vial and ball material & BPR \\
\hline SPEX 5100 & 2500 & $2.5 \mathrm{ml}$ & hardened steel & $10: 1$ \\
SPEX 8000M & 1425 & $8.8 \mathrm{ml}$ & hardened steel & $30: 1$ \\
\hline
\end{tabular}

*rotations per minute

Table 2. The sample labels

\begin{tabular}{cccc}
\hline Lable/Sample & Note & $\mathrm{MgH}_{2}(\mathrm{wt} . \%)$ & $\mathrm{WO}_{3}(\mathrm{wt} . \%)$ \\
\hline AA & as-received & 100 & - \\
AA30 & 30 min milled & 100 & - \\
5MW5 & SPEX 5100 & 95 & 5 \\
5MW10 & SPEX 5100 & 90 & 10 \\
5MW15 & SPEX 5100 & 85 & 15 \\
8MW5 & SPEX 8000M & 95 & 5 \\
8 MW10 & SPEX 8000M & 90 & 10 \\
8 MW15 & SPEX 8000M & 85 & 15 \\
\hline
\end{tabular}

X-ray powder diffraction (XRD) measurements were performed by Rigaku Ultima IV diffractometer with nickel-filtered $\mathrm{CuK} \alpha 1$ radiation $(\lambda=0.1540 \mathrm{~nm}$, operating at $40 \mathrm{kV}$ and 40 $\mathrm{mA}$ ) in order to determine the structure of obtained composites. The diffracted X-rays were collected over $2 \theta$ range $10-80^{\circ}$ using a step width of $0.02^{\circ}$ and measuring time 5 s per step. The surface morphology of samples was microstructurally characterized by scanning electron microscope SEM, JEOL JSM 6460LV. Particle size distribution analysis (PSA) was done by Malvern Mastersizer 2000 laser diffraction particle size analyzer. For PSA, samples were prepared by dispersing around $5 \mathrm{mg}$ of material in $10 \mathrm{~cm}^{3}$ of propan-2-ol. Since the samples tend to agglomerate, they were previously sonicated in a water bath for $3 \mathrm{~min}$. 
Desorption properties of samples were investigated with Differential Scanning Calorimetry (DSC) and Temperature Programmed Desorption (TPD). DSC measurements were performed by TA Instrument DSC Q10P with hydrogen gas flow at the heating rate of $5^{\circ} \mathrm{C} / \mathrm{min}$ in temperature interval from 30 to $500^{\circ} \mathrm{C}$. Samples were studied with TPD utilizing homemade equipment, where desorbed gaseous products were detected by a quadrupole mass spectrometer XTORR XT300 at a constant heating rate of $10^{\circ} \mathrm{C} / \mathrm{min}$ from room temperature to $500^{\circ} \mathrm{C}(773 \mathrm{~K})$.

\section{Results}

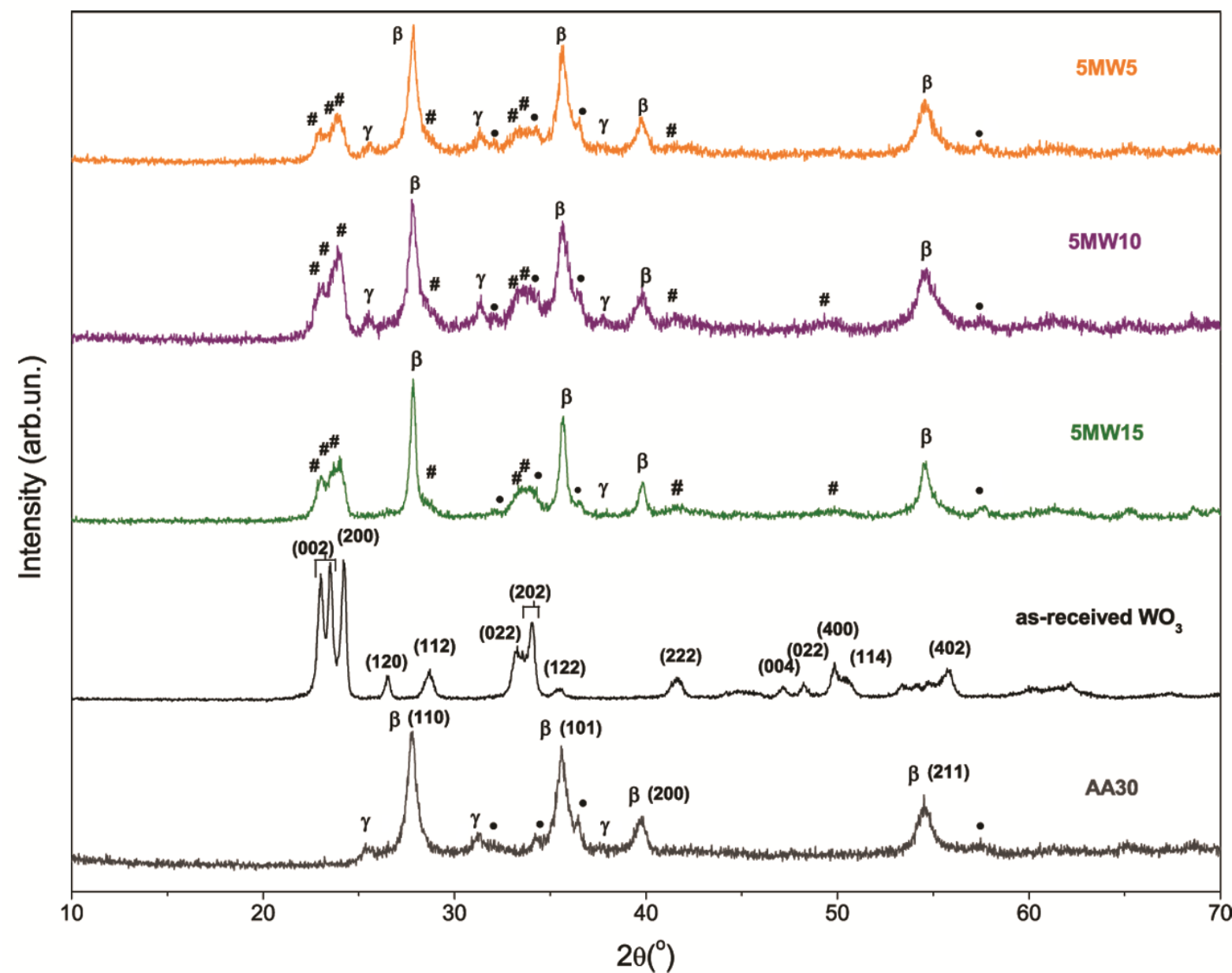

Figure 1. XRD profiles of $\mathrm{MgH}_{2}$ milled $30 \mathrm{~min}$, as-received $\mathrm{WO}_{3}$ and composites synthesized in SPEX 5100 with different quantity of $\mathrm{WO}_{3}: 5$ wt.\%, $10 \mathrm{wt} . \%$ and $15 \mathrm{wt} \%$; Legend: $\beta$ ( $\beta$ $\left.\mathrm{MgH}_{2}\right), \gamma\left(\gamma-\mathrm{MgH}_{2}\right)$, \# $\left(\mathrm{WO}_{3}\right), \cdot(\mathrm{Mg})$.

XRD profiles of composites with different quantity of $\mathrm{WO}_{3}(5,10$ and 15 wt.\%) obtained by mechanosynthesis in SPEX 5100 and SPEX 8000M are presented in Figure 1 and Figure 2, respectively. Reflections corresponding to tetragonal $\beta-\mathrm{MgH}_{2}$, metallic $\mathrm{Mg}$ and $\mathrm{WO}_{3}$ are present in all samples. The broadening of typical peaks corresponding to $\beta-\mathrm{MgH}_{2}$ tetragonal structure is observed in all composites indicating the reduction in crystallite size and accumulation of mechanical strain. Debye-Scherrer formula [37,51-53] applied on (110) peak and Williamson-Hall method are used to calculate the crystallite size of the powders. The peak broadening is more explicit in samples prepared in SPEX 8000M (see Table 3). If 
the sizes of crystallites lie between $5-50 \mathrm{~nm}$, the size is computed within the error of about several percents whether the Debye-Scherrer or Williamson-Hall method is applied [54]. After milling, the formation of metastable $\gamma-\mathrm{MgH}_{2}$ phase occurs [55]. Tetragonal (rutile, $\mathrm{P}_{2} /$ mnm [56]) $\beta$ phase transforms into a metastable orthorhombic phase under high compressive stress [57]. The high energy impact of the balls creates deformations and structural defects, and in that way increases the free energy of the system [58]. When the free energy is high, conditions are created to overcome the activation energy barrier and to form the metastable phase. Peaks that correspond to $\gamma$ phase are more intense in the diffractograms obtained from samples synthesized in SPEX 8000M. There are no reflections corresponding to crystal $\mathrm{MgO}$ or $\mathrm{Mg}(\mathrm{OH})_{2}$. One could argue that there is no significant oxygen contamination or that obtained oxygen species are amorphous. The decrease of crystallite size and higher quantities of $\gamma$ phase in samples milled in SPEX 8000M indicate a higher energy input in comparison to SPEX 5100. Irregularity in crystallite size in sample 5MW15 could be explained by cold welding of the grains due to short impact pathway in the smaller vial in SPEX 5100. Further, 15 wt.\% of the added $\mathrm{WO}_{3}$ appears to be boarding case in both, texture and kinetics as it can be seen from DSC/TPD results.

Table 3. Crystallite size of $\beta-\mathrm{MgH}_{2}$ phase obtained by Debye-Scherrer (D-S) and Williamson-Hall (W-H) method of samples prepared in SPEX 5100 and SPEX 8000M.

\begin{tabular}{cc|ccccc}
\hline \multirow{2}{*}{ Sample (5100) } & \multicolumn{2}{c}{ Crystallite size [nm] } & Sample (8000M) & \multicolumn{2}{c}{ Crystallite size [nm] } \\
\cline { 2 - 3 } \cline { 5 - 6 } & D-S & W-H & & D-S & W-H \\
\hline AA & 70 & 64 & 17 & AA & 70 & 64 \\
AA30 & 17 & AA30 & 14 & 14 \\
5MW5 & 19 & 18 & & 8MW5 & 12 & 11 \\
5MW10 & 19 & 16 & 8MW10 & 11 & 13 \\
5MW15 & 24 & 33 & & 8MW15 & 11 & 13 \\
\hline
\end{tabular}




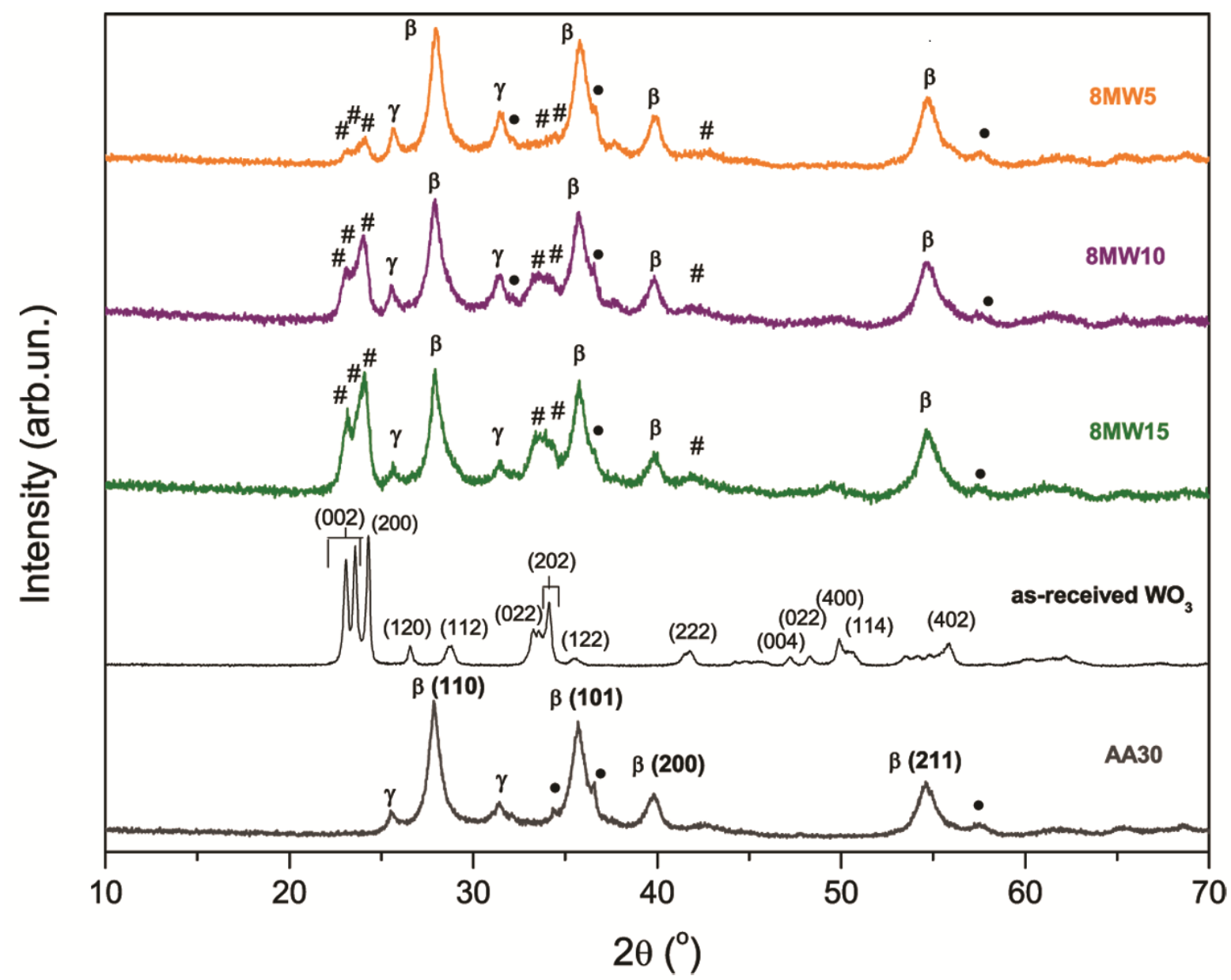

Figure 2. XRD profiles of $\mathrm{MgH}_{2}$ milled 30 min, as-received $\mathrm{WO}_{3}$ and composites synthesized in SPEX 8000M with different quantity of $\mathrm{WO}_{3}: 5$ wt. $\%, 10 \mathrm{wt} . \%$ and $15 \mathrm{wt} . \%$; Legend: $\beta$ $\left(\beta-\mathrm{MgH}_{2}\right), \gamma\left(\gamma-\mathrm{MgH}_{2}\right)$, \# $\left(\mathrm{WO}_{3}\right), \cdot(\mathrm{Mg})$.

As it can be seen from PSA curves, composites synthesized in SPEX 5100 show quite similar bimodal distribution (Figure 3a) in the range of $0.2-100 \mu \mathrm{m}$; in 5MW5 sample $46 \%$ in volume of particles has a mean particle size of $1.25 \mu \mathrm{m}$, while $54 \%$ of the sample has a mean particle size of $10 \mu \mathrm{m}$. Regarding the sample 5MW10, 44\% in volume has a mean particle size of $1.1 \mu \mathrm{m}$, while $56 \%$ of the sample has $15 \mu \mathrm{m}$. When it comes to $5 \mathrm{MW} 15$, the situation is quite alike, $41 \%$ in volume of the sample has a mean particle size of $1.25 \mu \mathrm{m}$ and $59 \%$ of the sample has a mean particle size of $13 \mu \mathrm{m}$. In comparison to these PSA curves, samples that have been synthesized in SPEX 8000M show polymodal particle size distribution (Figure $3 b)$ which can be distinguished from the shape of the curves. Similar results were obtained with the addition of $\mathrm{VO}_{2}$ and $\mathrm{NaBH}_{4}$ [31,43]. The pie charts in Figure 4 show shares of average particle size obtained from PSA. It is quite difficult to correlate the particle and the crystallite size with the addition of the additive. The crystallite size increases with the addition of $\mathrm{WO}_{3}$ in samples milled in SPEX 5100. On the other hand, the mean particle size values for composite samples milled in SPEX 5100 do not show the same trend, as it can be seen from Table 3. Regarding samples milled in SPEX 8000M no trend is observed. In both cases, we can notice the reduction of particle size in comparison to as-received $\mathrm{MgH}_{2}$ which can lead to better desorption properties. 

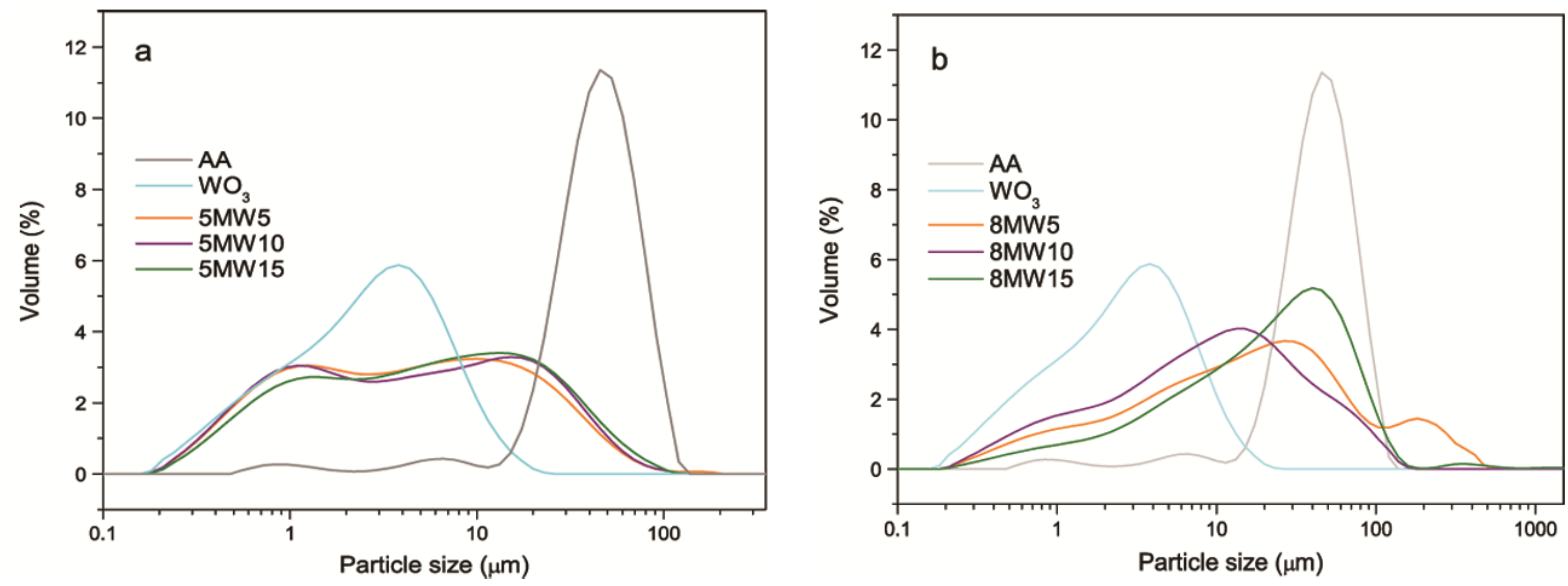

Figure 3. Particle size distribution curves obtained by PSA of as-received $\mathrm{MgH}_{2}$ powder, $\mathrm{WO}_{3}$ and $\mathrm{MgH}_{2}-\mathrm{WO}_{3}$ composites with different quantity of $\mathrm{WO}_{3}$ (5, 10, 15 wt.\%) synthesized in SPEX 5100 (a) and in SPEX 8000M (b)

a

5MW5
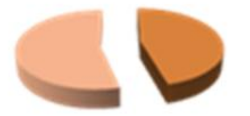

$1.25 \mu \mathrm{m}$
$10 \mu \mathrm{m}$

5MW10

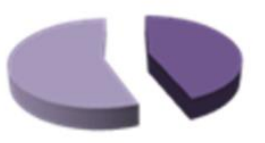

$1.1 \mu \mathrm{m}$

$15 \mu \mathrm{m}$

5MW15 b

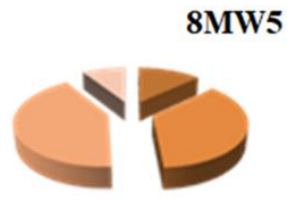

8MW10

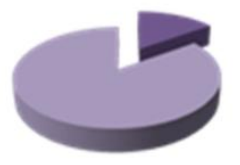

8MW15

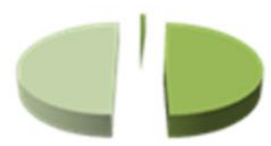

$830 \mathrm{~nm}$

a $5 \mu \mathrm{m}$

$36 \mu \mathrm{m}$

$212 \mu \mathrm{m}$

- $820 \mathrm{~nm}$

[- $13.5 \mu \mathrm{m}$

$950 \mathrm{~nm}$

$9 \mu \mathrm{m}$

$42 \mu \mathrm{m}$

Figure 4. Pie-chart presentation of particle size ratios in composites synthesized in SPEX 5100 (a) and in SPEX 8000M (b)

SEM micrographs of composites milled in both mills, SPEX 5100 (Figure 5a) and SPEX 8000M (Figure 5b) show irregular particle shape with sponge-like structure. The presence of agglomerates is also visible. Distribution of additive in $\mathrm{MgH}_{2}$ matrix can also be seen (bright particles). This is because tungsten is conductive material with higher atomic number in comparison to matrix, so it scatters electrons more strongly and thus appear brighter in the image [59]. Good distribution of additive is of great importance because it can significantly improve hydrogen desorption from $\mathrm{MgH}_{2}$ [43]. Additive in the form of oxide is easier to disperse homogeneously by milling [60]. 

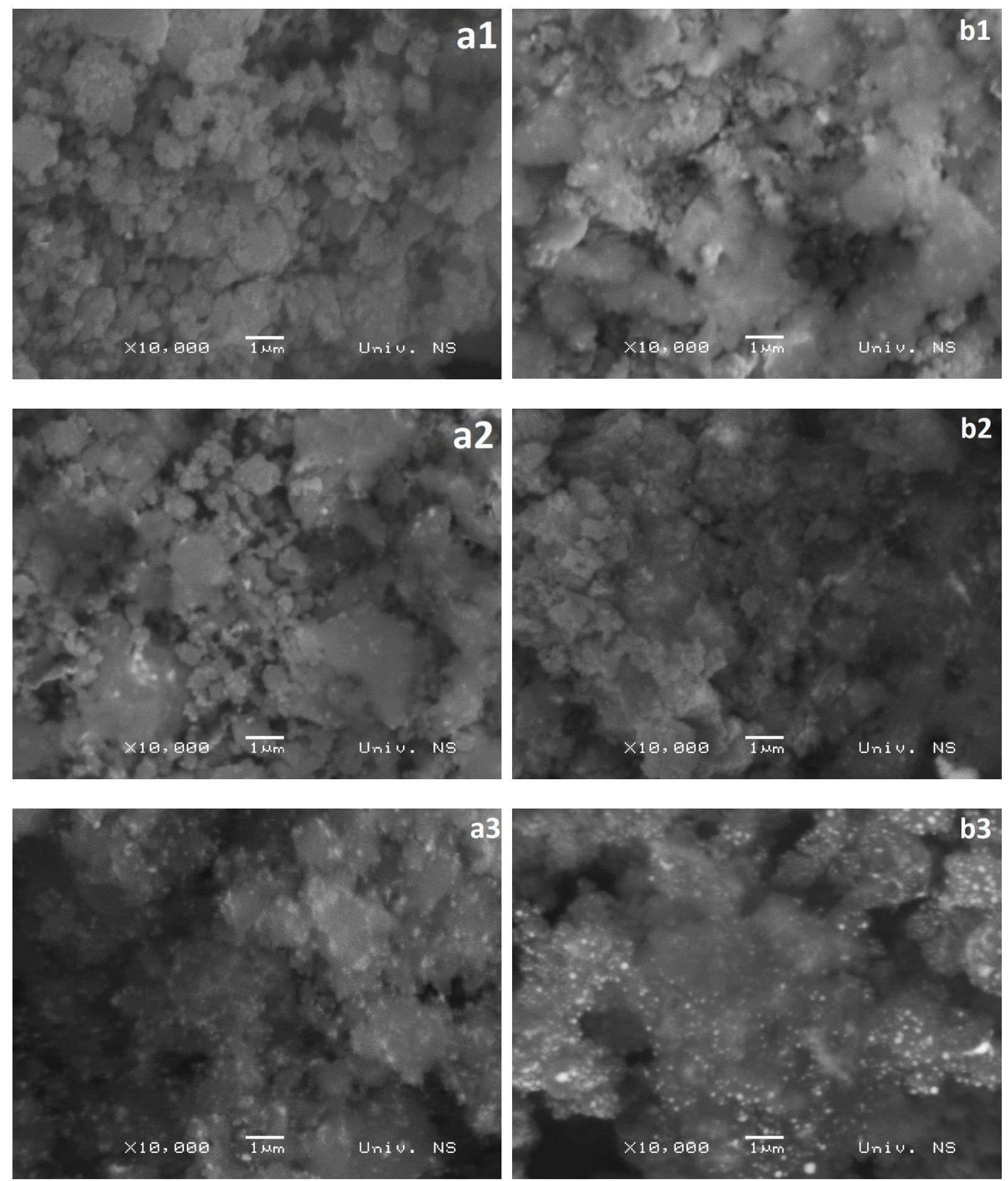

Figure 5. SEM micrographs of $\mathrm{MgH}_{2}-\mathrm{WO}_{3}$ composites with different quantity of $\mathrm{WO}_{3}$ synthesized in SPEX 5100 (a1-5MW5, a2-5MW10, a3-5MW15) and SPEX 8000M (b18MW5, b2-8MW10, b3-8MW15). 


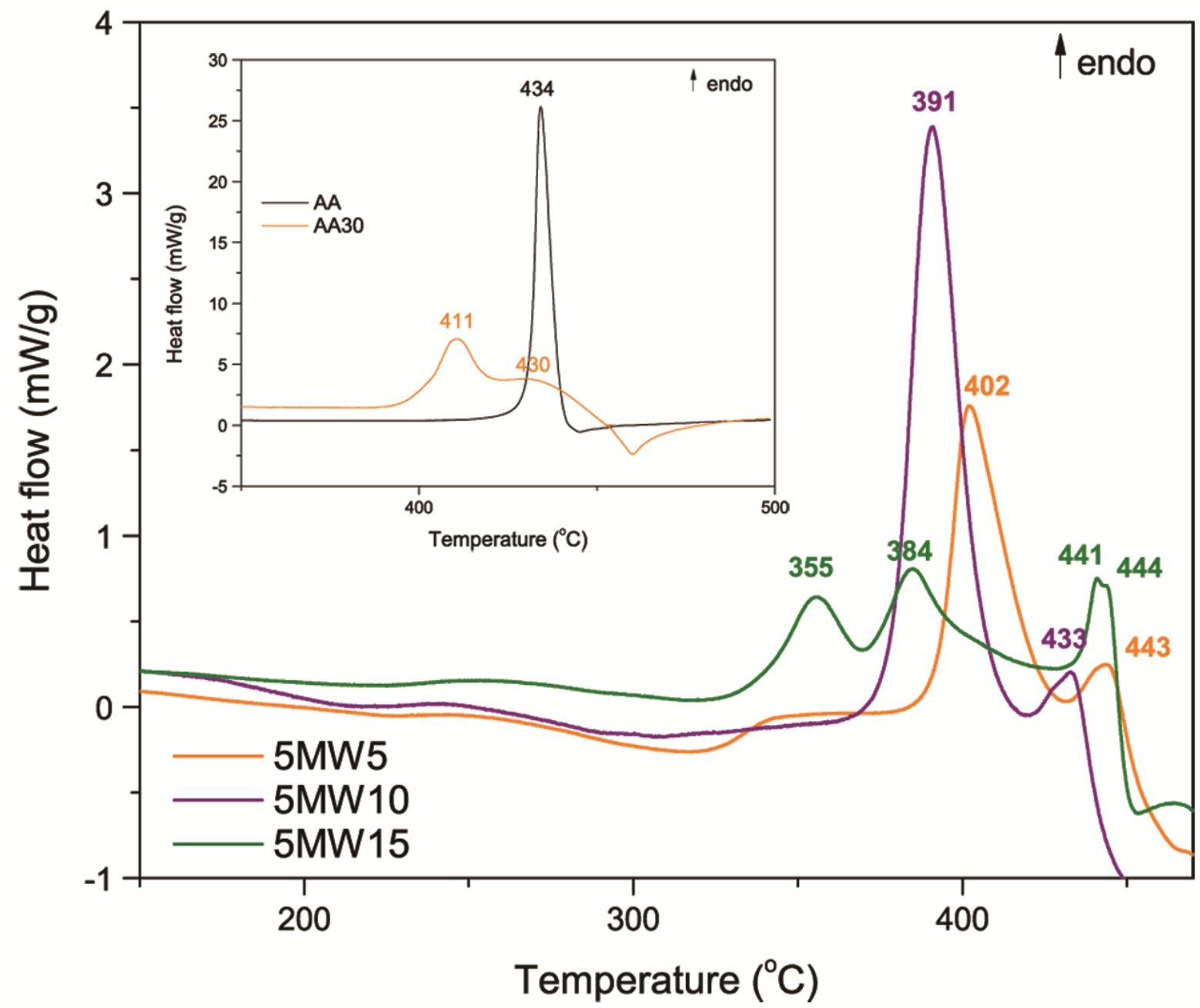

Figure 6. DSC curves of $\mathrm{MgH}_{2}-\mathrm{WO}_{3}$ composites with different quantity of $\mathrm{WO}_{3}(5,10,15$ wt.\%) synthesized in SPEX 5100. Insert: DSC curves of as-received $\mathrm{MgH}_{2}$ and $\mathrm{MgH}_{2}$ milled for $30 \mathrm{~min}$.

To better understand the thermal behavior of composites, DSC analysis was performed on as-received $\mathrm{MgH}_{2}$ sample (AA), 30 minutes milled $\mathrm{MgH}_{2}$ (AA30) and composites. The DSC curve of the as-received $\mathrm{MgH}_{2}$ (AA) shows only one strong endothermic peak at $434^{\circ} \mathrm{C}$, while $\mathrm{MgH}_{2}$ milled for 30 minutes (AA30) shows two desorption maxima at $411^{\circ} \mathrm{C}$ and $430^{\circ} \mathrm{C}$. Regarding the composites synthesized in SPEX 5100, 5MW5 and 5MW10 exhibit two endothermic peaks associated with hydrogen desorption: at $402^{\circ} \mathrm{C}$ and $443^{\circ} \mathrm{C}, 391^{\circ} \mathrm{C}$ and $433^{\circ} \mathrm{C}$ respectively (Figure 6). On the other hand, three endothermic peaks in 5MW15 composite were observed at 355,384 and $441^{\circ} \mathrm{C}$. Since the particle size distribution is similar, this can be attributed to the different crystallite i.e. grain size, amount of additive and the presence of $\gamma-\mathrm{MgH}_{2}[16,60]$. Gennari et al. suggested that the lowtemperature DSC peak corresponds to hydrogen desorption from $\gamma-\mathrm{MgH}_{2}$ and $\beta-\mathrm{MgH}_{2}$, and the high-temperature peak to the desorption from $\beta-\mathrm{MgH}_{2}[60]$.

DSC results for composites synthesized in SPEX 8000M are slightly different: curves corresponding to 8MW5 and 8MW10 displayed one endothermic peak (Figure 7) in a lower temperature range, at 366 and $375^{\circ} \mathrm{C}$ respectively, in comparison to composites from SPEX 
5100, while 8MW15 sample exhibits three endothermic peaks at 372,415 and $447^{\circ} \mathrm{C}$. The onset temperature of composites with 5 and $10 \mathrm{wt} . \%$ of $\mathrm{WO}_{3}$ synthesized in SPEX $8000 \mathrm{M}$ drops by $70^{\circ} \mathrm{C}$ with respect to the samples with the same amount of additive synthesized in SPEX 5100. Temperatures at peak maxima are listed in Table 4 for clarity.

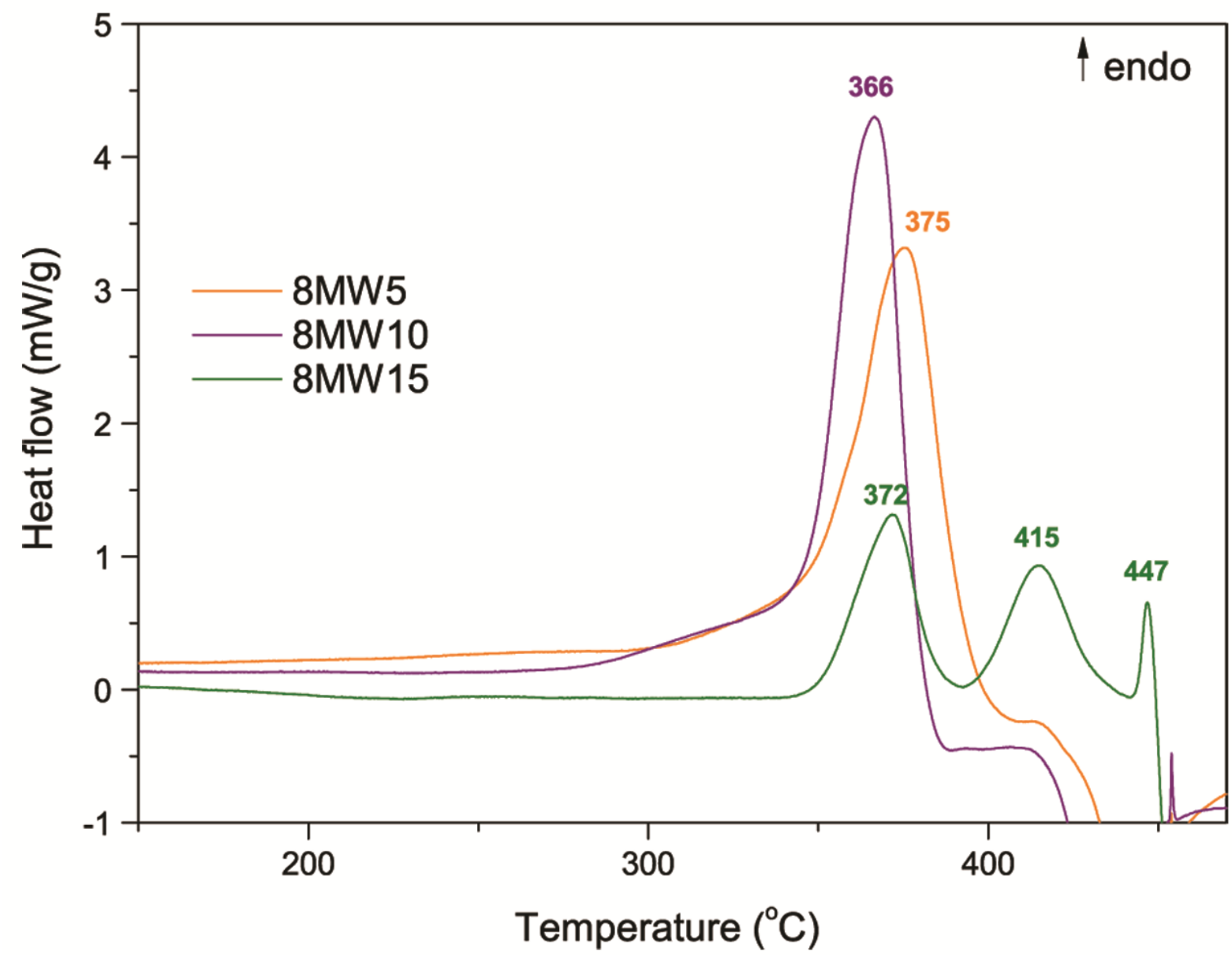

Figure 7. DSC curves of $\mathrm{MgH}_{2}-\mathrm{WO}_{3}$ composites with different quantity of $\mathrm{WO}_{3}(5,10,15$ wt.\%) synthesized in SPEX 8000M.

Table 4. Desorption temperatures obtained from DSC curves for samples milled in SPEX 5100 and 8000M (bold is for samples milled in SPEX 8000M)

\begin{tabular}{l|llll}
\hline Sample- & $\mathrm{T}_{\text {onset }}\left[{ }^{\circ} \mathrm{C}\right]$ & Peak $1\left[{ }^{\circ} \mathrm{C}\right]$ & Peak $2\left[{ }^{\circ} \mathrm{C}\right]$ & Peak $3\left[{ }^{\circ} \mathrm{C}\right]$ \\
SPEX5100/8000M & & 434 & & \\
\hline AA & & 411 & 430 & \\
$\mathrm{AA30}$ & $385 / 310$ & $402 / 375$ & 443 & \\
$\mathrm{MgH}_{2}-5 \mathrm{WO}_{3}$ & $365 / 295$ & $391 / 366$ & 433 & $441 / 447$ \\
$\mathrm{MgH}_{2}-10 \mathrm{WO}_{3}$ & $325 / 346$ & $355 / 372$ & $384 / 415$ & \\
$\mathrm{MgH}_{2}-15 \mathrm{WO}_{3}$ & & & & \\
\hline
\end{tabular}

The results of TPD measurements related to $\mathrm{H}_{2}$ desorption are presented in Figure 8 . for composites milled in both mills, SPEX 5100 (a) and SPEX 8000M (b). The as-received sample (AA) completely releases hydrogen in the single process at $445^{\circ} \mathrm{C}$. It can be noticed 
that the addition of $\mathrm{WO}_{3}$ to all milling blends clearly moves desorption maxima to lower temperatures. Samples obtained in SPEX 8000M (Fig.8b) follow the trend where desorption peaks are shifting to lower temperatures as the quantities of additive is raising. In the case of samples obtained from SPEX 5100 (Fig.8a), this is not that obvious because desorption of hydrogen takes place in two stages and peaks are broad. Two asymmetric desorption maxima are visible for all composite samples. This behavior suggests the existence of different mechanisms of hydrogen release, and/or differently bonded hydrogen atoms in the samples (Figure 8) [61-63]. With the addition of $\mathrm{WO}_{3}$, separation of desorption stages becomes more pronounced, which is probably associated with a number of created fresh grain boundaries i.e. interfaces between $\mathrm{MgH}_{2}$ and TMO. The reaction of released hydrogen with $\mathrm{WO}_{3}$ has to be taken into account too. The maximum number of boundaries is achieved in the sample with $10 \%$ of added $\mathrm{WO}_{3}$ and further addition does not improve the sorption properties. This is valid also for samples milled in SPEX 5100. Further, the high energy input on samples milled in SPEX 5100 leads to unresolved peaks which can be attributed to agglomeration of samples.

On the other hand, samples milled in SPEX 8000M show clear onset for both high (HT) and low (LT) temperature peak. The existence of multiple peaks in TPD spectra could be related to both, different particle sizes and the presence of gamma phase $[16,64,65]$. As shown in Table 5, LT maximum is dominant for all composites and is positioned at around $370^{\circ} \mathrm{C}$ regardless the energy input or quantity of added oxides.
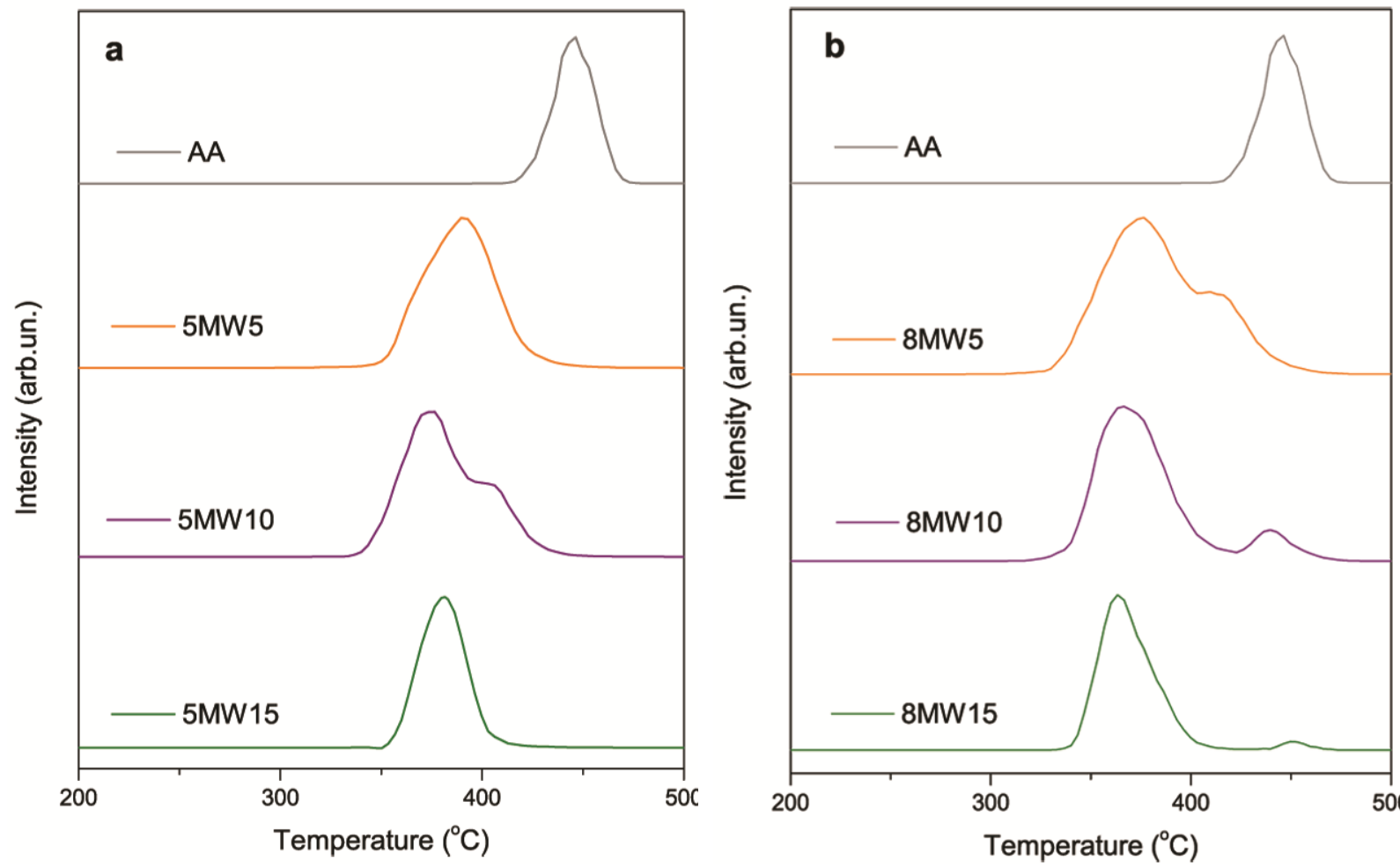

Figure 8. TPD curves of as-received $\mathrm{MgH}_{2}$ and $\mathrm{MgH}_{2}-\mathrm{WO}_{3}$ composites with different quantity of $\mathrm{WO}_{3}(5,10,15$ wt.\%) synthesized in SPEX 5100 (a) and in SPEX 8000M (b)

The $\mathrm{H}_{2}$ desorption process from composites was analyzed by fitting the experimental data using different kinetic models $[29,66]$. The kinetics of the reaction can be described by 
$\left[-\ln (1-\theta)^{1 / n}\right]=k t$ equation where $\mathrm{n}$ is the parameter depending on the mechanism of nucleation and growth.

Table 5. Desorption temperature of $\mathrm{H}_{2}$ obtain from TPD measurements for all $\mathrm{MgH}_{2}-\mathrm{WO}_{3}$ milling blends

\begin{tabular}{ccccc}
\hline Sample & $\begin{array}{c}\text { Temperature } \\
(\mathbf{H T})\left[{ }^{\circ} \mathbf{C}\right]\end{array}$ & $\begin{array}{c}\mathbf{E}_{\text {appHT }} \\
{[\mathbf{k J} / \mathbf{m o l}]}\end{array}$ & $\begin{array}{c}\text { Temperature } \\
(\mathbf{L T})\left[{ }^{\circ} \mathbf{C}\right]\end{array}$ & $\begin{array}{c}\mathbf{E}_{\text {appLT }} \\
{[\mathbf{k J} / \mathbf{m o l}]}\end{array}$ \\
\hline AA & 445 & $146^{*}$ & & \\
$\mathbf{5 M W 5}$ & 389 & 66 & 373 & 64 \\
$\mathbf{5 M W 1 0}$ & 406 & 88 & 373 & 125 \\
$\mathbf{5 M W 1 5}$ & 387 & 142 & 373 & 43 \\
$\mathbf{8 M W 5}$ & 416 & 71 & 370 & 49 \\
$\mathbf{8 M W 1 0}$ & 439 & 85 & 363 & 66 \\
\hline $\mathbf{8 M W 1 5}$ & 454 & 195 & $\mathrm{~kJ}$ & \\
\hline
\end{tabular}

*The apparent activation energy obtained from peak corresponding to the as-received $\mathrm{MgH}_{2}$ is $146 \mathrm{~kJ} / \mathrm{mol}$ and is in accordance with the literature values which may vary from 120 to $160 \mathrm{~kJ} / \mathrm{mol}[55,67,68]$.

The analysis of TPD curves indicates that the $\mathrm{H}_{2}$ desorption from $\mathrm{MgH}_{2}-\mathrm{WO}_{3}$ composites is controlled by nucleation and growth mechanisms with Avrami parameter $\mathrm{n}=4$ over a $\theta$ range from 0.2 to 0.8 (Figure 9). Although the desorption from pure $\mathrm{MgH}_{2}$ is governed by the same mechanism, the Avrami parameter is 3. By comparing the apparent activation energies $\mathrm{E}_{\text {app }}$ for the as-received $\mathrm{MgH}_{2}$ and composite samples it is evident that the addition of $\mathrm{WO}_{3}$ gives better desorption kinetics. The obtained apparent activation energies are similar to those found in the literature (Table 6.) 


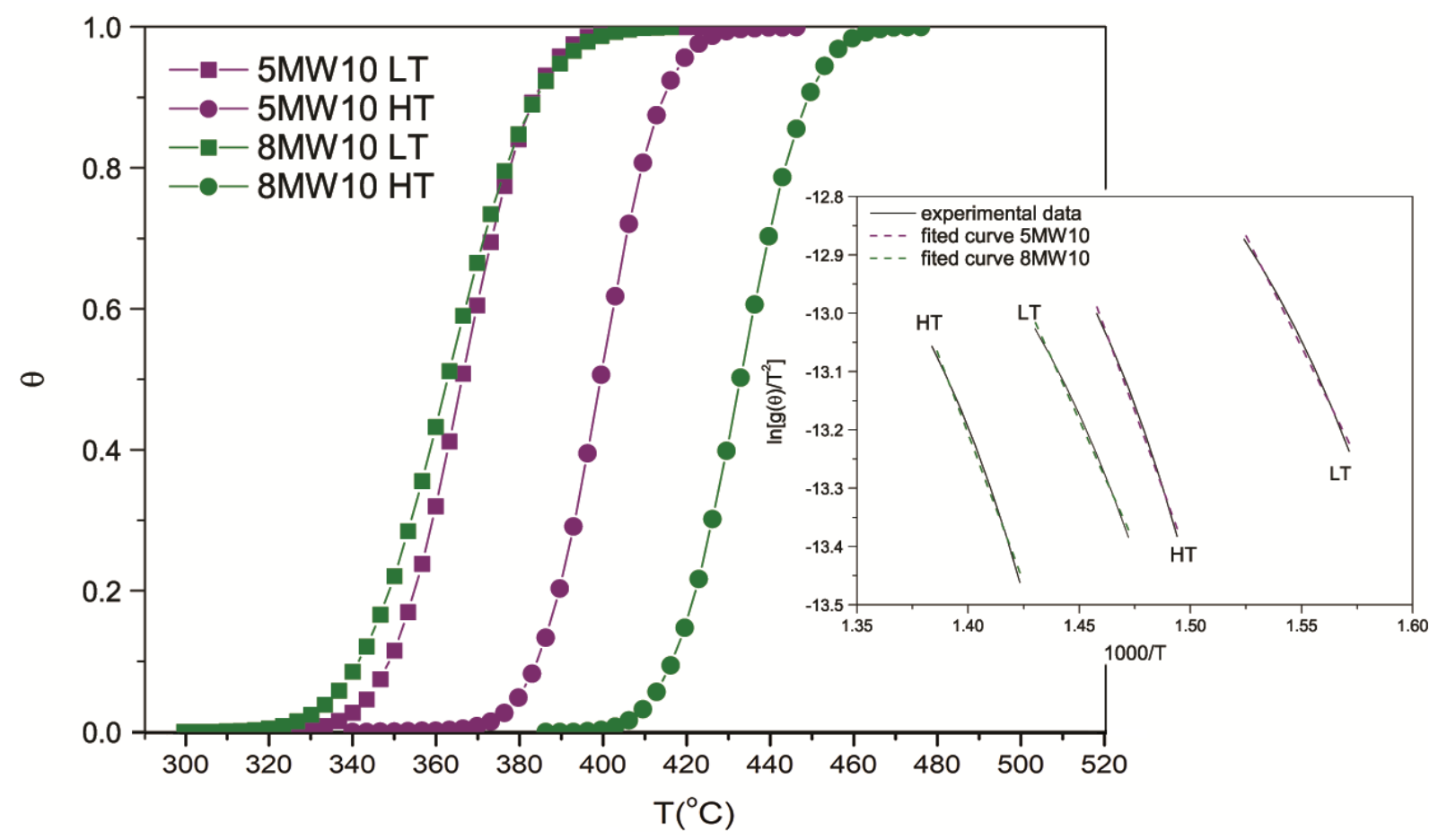

Figure 9. Temperature evolution of the reacted fraction $(\theta)$ corresponding to $\mathrm{MgH}_{2}$ decomposition, obtained by integration of peaks for 5MW10 and 8MW10 samples; Insert: experimental data and best fit obtained for nucleation model $g(\theta)=[-\ln (1-\theta)]^{1 / n}$

Table 6. The apparent activation energy of different composites obtained from the literature

\begin{tabular}{cccc}
\hline References & Composite & Milling time & $\begin{array}{c}\mathbf{E}_{\text {app }} \\
{\left[\mathbf{k J} / \mathbf{m o l} \mathbf{H}_{2}\right]}\end{array}$ \\
\hline$[69]$ & $\mathrm{MgH}_{2}-\mathrm{Nb}_{2} \mathrm{O}_{5}$ & $20 \mathrm{~h}$ & 62 \\
{$[70]$} & $\mathrm{MgH}_{2}-\mathrm{Cr}_{2} \mathrm{O}_{3}$ & $20 \mathrm{~h}$ & 84 \\
{$[71]$} & $\mathrm{MgH}_{2}-\mathrm{MnFe}_{2} \mathrm{O}_{4}$ & $30 \mathrm{~min}$ & 64 \\
{$[72]$} & $\mathrm{MgH}_{2}-\mathrm{TiO}_{2}$ & $20 \mathrm{~h}$ & 72 \\
{$[70]$} & $\mathrm{MgH}_{2}-\mathrm{TiO}_{2}$ & $20 \mathrm{~h}$ & 94 \\
{$[64]$} & $\mathrm{MgH}_{2}-\mathrm{CeO}_{2}$ & $10 \mathrm{~h}$ & 60 \\
{$[43]$} & $\mathrm{MgH}_{2}-\mathrm{VO}_{2}$ & $2 \mathrm{~h}$ & 65 \\
Current study & $5 \mathrm{MW5}$ & $30 \mathrm{~min}$ & 66 \\
Current study & $8 \mathrm{MW5}$ & $30 \mathrm{~min}$ & 71 \\
\hline
\end{tabular}

It has been argued that the addition of TMO can assist the dissociation/recombination of hydrogen on magnesium surface and therefore improve $\mathrm{H}$ sorption in magnesium $[69,73-$ 75]. In fact, $\mathrm{WO}_{3}$ is an efficient process control agent which creates crystal defects, lattice distortion, increase of specific surface area, increase of active sorption sites density and reduction of the effective diffusion length for sorption (by a decrease of the average interparticle distance) $[43,76]$. The shape analysis of TPD spectra leads to several additional conclusions. Asymmetry of the peaks is related to noticeable surface heterogeneity thus variable apparent activation energies for desorption (Table 5). Re-adsorption also has to be 
taken into account during the entire process, since the surface area is covered with species previously desorbed.

\section{Conclusions}

This paper deals with the influence of different milling conditions on $\mathrm{MgH}_{2}-\mathrm{WO}_{3}$ milling bland obtained by two SPEX mills (5100 and 8000M). It has been shown by SEM analysis that even though the energy input is different, the dispersion of additive particles is uniform in both cases. On the other hand, the mechanical milling in SPEX mill 5100 leads to a bimodal particle size distribution, while milling in SPEX 8000M gives polymodal distribution. DSC results show that better reduction of desorption temperature occurred in samples milled in SPEX $8000 \mathrm{M}$ : reduction of around $70^{\circ} \mathrm{C}$ is obtained. Desorption temperatures of samples milled in SPEX 5100 were reduced for about $40^{\circ} \mathrm{C}$. Such behavior can be correlated to smaller crystallite size of samples obtained in SPEX 8000M mill. In the case when the reduction of particle size is accompanied by a reduction of crystallite size, it was not clear which factor is primarily responsible for the improvement of hydrogen storage properties. So, one can conclude that the increase of a number of grain boundaries which act as active sites for nucleation of new phase plays a decisive role in desorption. The presence of a higher number of smaller crystallites is more important in facilitating hydrogen sorption than having small but uniform particles. According to the TPD analysis, the surface heterogeneity is more pronounced for samples milled with higher energy input, leading to a smaller decrease of apparent activation energy for desorption for both LT and HT maxima.

\section{Acknowledgment}

This research was financially supported by The Ministry of Education, Science and Technology of the Republic of Serbia under grant III 45012. This work is also supported by the Environmental Protection and Energy Efficiency Fund of the Republic of Croatia and the Croatian Science Foundation, project no. PKP-2016-06-4480.

\section{References}

[1] Fatay D, Revesz A, Spassov T. Particle size and catalytic effect on the dehydriding of $\mathrm{MgH}_{2}$. J Alloys Compd 2005;399:237-41. doi:10.1016/j.jallcom.2005.02.043.

[2] Kurko S, Milanović I, Grbović Novaković J, Ivanović N, Novaković N. Investigation of surface and near-surface effects on hydrogen desorption kinetics of $\mathrm{MgH}_{2}$. Int $\mathrm{J}$ Hydrogen Energy 2014;39:862-7. doi:10.1016/j.ijhydene.2013.10.107.

[3] Kurko S, Paskaš Mamula B, Rmuš J, Grbović Novaković J, Novaković N. DFT study of boron doped $\mathrm{MgH}_{2}$ : Bonding mechanism, hydrogen diffusion and desorption. Int $\mathrm{J}$ Hydrogen Energy 2019. doi:10.1016/J.IJHYDENE.2019.05.015.

[4] Balaz P. High-Energy Milling. Mechanochemistry Nanosci. Miner. Eng., Berlin: Springer-Verlag; 2008, p. 103-32.

[5] Reid CB, Forrester JS, Goodshaw HJ, Kisi EH, Suaning GJ. A study in the mechanical 
milling of alumina powder. Ceram Int 2008;34:1551-6.

doi:10.1016/j.ceramint.2007.05.003.

[6] Suryanarayana C. Mechanical alloying and milling. Prog Mater Sci 2001;46:1-184. doi:10.1016/S0079-6425(99)00010-9.

[7] Chin Z-H, Perng TP. Amorphization of Ni-Si-C Ternary Alloy Powder by Mechanical Alloying. Mater Sci Forum 2009;235-238:121-6. doi:10.4028/www.scientific.net/msf.235-238.121.

[8] Cermak J, Kral L, Roupcova P. Improvement of hydrogen storage kinetics in ballmilled magnesium doped with antimony. Int J Hydrogen Energy 2017;42:6144-51. doi:10.1016/j.ijhydene.2016.11.113.

[9] Kis-Varga M, Beke DL. Phase Transitions in Cu-Sb Systems Induced by Ball Milling. Mater Sci Forum 2009;225-227:465-70. doi:10.4028/www.scientific.net/msf.225227.465 .

[10] Patah A, Takasaki A, Szmyd JS. Influence of multiple oxide $\left(\mathrm{Cr}_{2} \mathrm{O}_{3} / \mathrm{Nb}_{2} \mathrm{O}_{5}\right)$ addition on the sorption kinetics of $\mathrm{MgH}_{2}$. Int J Hydrogen Energy 2009;34:3032-7. doi:10.1016/j.ijhydene.2009.01.086.

[11] Lal C, Jain IP. Effect of ball milling on structural and hydrogen storage properties of Mg - X wt\% FeTi (x=2 \& 5) solid solutions. Int J Hydrogen Energy 2012;37:3761-6. doi:10.1016/j.ijhydene.2011.06.042.

[12] Kumar S, Singh PK, Rao GN, Kojima Y, Kain V. Synergic effect of vanadium trichloride on the reversible hydrogen storage performance of the $\mathrm{Mg}-\mathrm{MgH}_{2}$ system. Int J Hydrogen Energy 2018;43:15330-7. doi:10.1016/j.ijhydene.2018.06.063.

[13] Zhang D, Qin M, Zhang L, Lu X, Qu X. Effect of BPR on the Preparation of Nb-Base Powder via Ball Milling. Adv Mater Res 2012;535-537:2554-8.

doi:10.4028/www.scientific.net/amr.535-537.2554.

[14] Biyik S, Aydin M. Optimization of mechanical alloying parameters of $\mathrm{Cu}_{25} \mathrm{~W}$ electrical contact material. Acta Phys Pol A 2017;132:909-12. doi:10.12693/APhysPolA.132.909.

[15] Varin RA, Czujko T, Wronski ZS. Nanomaterials for Solid State Hydrogen Storage. Springer US; 2009.

[16] Varin RA, Czujko T, Wronski Z. Particle size, grain size and $\gamma-\mathrm{MgH}_{2}$ effects on the desorption properties of nanocrystalline commercial magnesium hydride processed by controlled mechanical milling. Nanotechnology 2006;17:3856-65. doi:10.1088/09574484/17/15/041.

[17] Milanović I, Biliškov N. Mechanochemical pretreatment of ammonia borane: A new procedure for sodium amidoborane synthesis. Int J Hydrogen Energy 2019. doi:10.1016/J.IJHYDENE.2019.06.042.

[18] Ali M. Processing Research Transformation and powder Characteristics of $\mathrm{TiO}_{2}$ during high energy milling. J Ceram Process Res 2014;15:290-3.

doi:10.1023/A:1026751017284. 
[19] Tomiczek B, Dobrzański LA, Adamiak M, Labisz K. Effect of Milling Conditions on Microstructure and Properties of AA6061/halloysite Composites. Procedia Manuf 2015;2:402-7. doi:10.1016/j.promfg.2015.07.071.

[20] Zakeri M, Ramezani M, Nazari A. Effect of ball to powder weight ratio on the mechanochemical synthesis of $\mathrm{MoSi}_{2}$-TiC nanocomposite powder. Mater Res 2012;15:891-7. doi:10.1590/s1516-14392012005000111.

[21] Pan X, Ma X. Phase transformations in nanocrystalline $\mathrm{TiO}_{2}$ milled in different milling atmospheres. J Solid State Chem 2004;177:4098-103. doi:10.1016/j.jssc.2004.08.017.

[22] Francke M, Hermann H, Wenzel R, Seifert G, Wetzig K. Modification of carbon nanostructures by high energy ball-milling under argon and hydrogen atmosphere. Carbon N Y 2005;43:1204-12. doi:10.1016/j.carbon.2004.12.013.

[23] Yuan Q, Zheng Y, Yu H. Mechanism of synthesizing nanocrystalline TiC in different milling atmospheres. Int J Refract Met Hard Mater 2009;27:696-700.

doi:10.1016/j.ijrmhm.2008.11.003.

[24] Biliškov N, Borgschulte A, Užarević K, Halasz I, Lukin S, Milošević S, et al. In-Situ and Real-time Monitoring of Mechanochemical Preparation of $\mathrm{Li}_{2} \mathrm{Mg}\left(\mathrm{NH}_{2} \mathrm{BH}_{3}\right)_{4}$ and $\mathrm{Na}_{2} \mathrm{Mg}\left(\mathrm{NH}_{2} \mathrm{BH}_{3}\right)_{4}$ and Their Thermal Dehydrogenation. Chem - A Eur J 2017;23:16274-82. doi:10.1002/chem.201702665.

[25] Bogdanovic B, Felderhoff M, Streukens G. Hydrogen storage in complex metal hydrides. J Serbian Chem Soc 2009;74:183-96. doi:10.2298/jsc0902183b.

[26] Czujko T, Zaranski Z, Malka IE, Wronski Z. Composite behaviour of $\mathrm{MgH}_{2}$ and complex hydride mixtures synthesized by ball milling. J Alloys Compd 2011;509:S604-7. doi:10.1016/J.JALLCOM.2010.08.133.

[27] Zhang Y, Tian Q. The reactions in $\mathrm{LiBH}_{4}-\mathrm{NaNH}_{2}$ hydrogen storage system. Int $\mathbf{J}$ Hydrogen Energy 2011;36:9733-42. doi:10.1016/J.IJHYDENE.2011.05.035.

[28] Leng HY, Ichikawa T, Isobe S, Hino S, Hanada N, Fujii H. Desorption behaviours from metal-N-H systems synthesized by ball milling. J Alloys Compd 2005;404406:443-7. doi:10.1016/J.JALLCOM.2004.09.082.

[29] Milanović I, Milošević S, Matović L, Vujasin R, Novaković N, Checchetto R, et al. Hydrogen desorption properties of $\mathrm{MgH}_{2} / \mathrm{LiAlH}_{4}$ composites. Int J Hydrogen Energy 2013;38:12152-8. doi:10.1016/j.ijhydene.2013.05.020.

[30] Milanović I, Milošević S, Rašković-Lovre Ž, Novaković N, Vujasin R, Matović L, et al. Microstructure and hydrogen storage properties of $\mathrm{MgH}_{2}-\mathrm{TiB}_{2}-\mathrm{SiC}$ composites. Ceram Int 2013;39:4399-405. doi:10.1016/j.ceramint.2012.11.029.

[31] Kurko S, Aurora A, Gattia DM, Contini V, Montone A, Rašković-Lovre Ž, et al. Hydrogen sorption properties of $\mathrm{MgH}_{2} / \mathrm{NaBH}_{4}$ composites. Int J Hydrogen Energy 2013;38:12140-5. doi:10.1016/j.ijhydene.2013.04.075.

[32] Kurko S, Rašković Ž, Novaković N, Paskaš Mamula B, Jovanović Z, Baščarević Z, et al. Hydrogen storage properties of $\mathrm{MgH}_{2}$ mechanically milled with $\alpha$ and $\beta \mathrm{SiC}$. Int $\mathrm{J}$ Hydrogen Energy 2011;36:549-54. doi:10.1016/j.ijhydene.2010.07.022. 
[33] Milošević S, Milanović I, Mamula BP, Đukić A, Rajnović D, Pasquini L, et al. Hydrogen desorption properties of $\mathrm{MgH}_{2}$ catalysed with $\mathrm{NaNH}_{2}$. Int $\mathrm{J}$ Hydrogen Energy 2013;38:12223-9. doi:10.1016/j.ijhydene.2013.06.083.

[34] Shang CX, Bououdina M, Guo ZX. Structural stability of mechanically alloyed (Mg + $10 \mathrm{Nb})$ and $\left(\mathrm{MgH}_{2}+10 \mathrm{Nb}\right)$ powder mixtures. J Alloys Compd 2003;349:217-23. doi:10.1016/S0925-8388(02)00920-9.

[35] Gasan H, Celik ON, Aydinbeyli N, Yaman YM. Effect of V, Nb, Ti and graphite additions on the hydrogen desorption temperature of magnesium hydride. Int $\mathbf{J}$ Hydrogen Energy 2012;37:1912-8. doi:10.1016/j.ijhydene.2011.05.086.

[36] Liang G, Huot J, Boily S, Neste A Van, Schulz R. Catalytic effect of transition metals on hydrogen sorption in nanocrystalline 1999;292:247-52.

[37] Yu H, Bennici S, Auroux A. Hydrogen storage and release: Kinetic and thermodynamic studies of $\mathrm{MgH}_{2}$ activated by transition metal nanoparticles. Int J Hydrogen Energy 2014;39:11633-41. doi:10.1016/j.ijhydene.2014.05.069.

[38] Oelerich W, Klassen T, Bormann R. Mg-Based Hydrogen Storage Materials with Improved Hydrogen Sorption. Mater Trans 2001;42:1588-92.

[39] Oelerich W, Klassen T, Bormann R. Metal oxides as catalysts for improved hydrogen sorption in nanocrystalline Mg-based materials. J Alloys Compd 2001;315:237-42. doi:10.1016/S0925-8388(00)01284-6.

[40] Aguey-Zinsou KF, Ares Fernandez JR, Klassen T, Bormann R. Effect of $\mathrm{Nb}_{2} \mathrm{O}_{5}$ on $\mathrm{MgH}_{2}$ properties during mechanical milling. Int J Hydrogen Energy 2007;32:2400-7. doi:10.1016/j.ijhydene.2006.10.068.

[41] Polanski M, Bystrzycki J, Varin RA, Plocinski T, Pisarek M. The effect of chromium (III) oxide $\left(\mathrm{Cr}_{2} \mathrm{O}_{3}\right)$ nanopowder on the microstructure and cyclic hydrogen storage behavior of magnesium hydride $\left(\mathrm{MgH}_{2}\right)$. J Alloys Compd 2011;509:2386-91. doi:10.1016/j.jallcom.2010.11.026.

[42] Jia Y, Zou J, Yao X. Catalytically enhanced dehydrogenation of $\mathrm{MgH}_{2}$ by activated carbon supported Pd-VOx (x=2.38) nanocatalyst. Int J Hydrogen Energy 2012;37:13393-9. doi:10.1016/j.ijhydene.2012.06.063.

[43] Milošević S, Kurko S, Pasquini L, Matović L, Vujasin R, Novaković N, et al. Fast hydrogen sorption from $\mathrm{MgH}_{2}-\mathrm{VO}_{2}(\mathrm{~B})$ composite materials. J Power Sources 2016;307:481-8. doi:10.1016/j.jpowsour.2015.12.108.

[44] Zaluska A, Zaluski L, Ström-Olsen JO. Nanocrystalline magnesium for hydrogen storage. J Alloys Compd 1999;288:217-25. doi:10.1016/S0925-8388(99)00073-0.

[45] Friedrichs O, Martínez-Martínez D, Guilera G, López JCS, Fernández A. In situ energy-dispersive XAS and XRD study of the superior hydrogen storage system $\mathrm{MgH}_{2} / \mathrm{Nb}_{2} \mathrm{O}_{5}$. J Phys Chem C 2007;111:10700-6. doi:10.1021/jp0675835.

[46] Friedrichs O, Sánchez-López JC, López-Cartes C, Klassen T, Bormann R, Fernández A. $\mathrm{Nb}_{2} \mathrm{O}_{5}$ "pathway effect" on hydrogen sorption in $\mathrm{Mg}$. J Phys Chem B 2006;110:7845-50. doi:10.1021/jp0574495. 
[47] Bazzanella N, Checchetto R, Miotello A, Sada C, Mazzoldi P, Mengucci P. Hydrogen kinetics in magnesium hydride: On different catalytic effects of niobium. Appl Phys Lett 2006;89:2004-7. doi:10.1063/1.2218328.

[48] Checchetto R, Bazzanella N, Miotello A, Mengucci P. $\mathrm{H}_{2}$ storage efficiency and sorption kinetics in composite materials. J Phys Chem Solids 2008;69:2160-3. doi:10.1016/j.jpcs.2008.03.032.

[49] Cui J, Wang H, Liu J, Ouyang L, Zhang Q, Sun D, et al. Remarkable enhancement in dehydrogenation of $\mathrm{MgH}_{2}$ by a nano-coating of multi-valence Ti-based catalysts. J Mater Chem A 2013;1:5603-11. doi:10.1039/c3ta01332d.

[50] Suryanarayana C. Mechanical Alloying and Milling. vol. XXXIII. New York: Marcel Dekker; 2004.

[51] Jalil Z, Rahwanto A, Ismail I, Sofyan H, Handoko E. The use of nano-silicon carbide and nickel as catalyst in magnesium hydrides $\left(\mathrm{MgH}_{2}\right)$ for hydrogen storage material application. Mater Res Express 2018;5:64002. doi:10.1088/2053-1591/aaca84.

[52] Floriano R, Leiva DR, Deledda S, Hauback BC, Botta WJ. Nanostructured $\mathrm{MgH}_{2}$ obtained by cold rolling combined with short-time high-energy ball milling. Mater Res 2012;16:158-63. doi:10.1590/S1516-14392012005000162.

[53] Vorokh AS. Scherrer formula: estimation of error in determining small nanoparticle size. Nanosyst Physics, Chem Math 2018;9:364-9. doi:10.17586/2220-8054-2018-9-3364-369.

[54] Waseda Y, Matsubara E, Shinoda K. X-Ray Diffraction Crystallography. Berlin, Heidelberg: Springer Berlin Heidelberg; 2011. doi:10.1007/978-3-642-16635-8.

[55] Huot J, Liang G, Boily S, Van Neste A, Schulz R. Structural study and hydrogen sorption kinetics of ball-milled magnesium hydride. J Alloys Compd 1999;293:495500. doi:10.1016/S0925-8388(99)00474-0.

[56] Novaković N, Grbović Novaković J, Matović L, Manasijević M, Radisavljević I, Paskaš Mamula B, et al. Ab initio calculations of $\mathrm{MgH}_{2}, \mathrm{MgH}_{2}: \mathrm{Ti}$ and $\mathrm{MgH}_{2}: \mathrm{Co}$ compounds. Int J Hydrogen Energy 2010;35:598-608.

doi:10.1016/j.ijhydene.2009.11.003.

[57] San-Martin A, Manchester FD. The H-Mg (Hydrogen-Magnesium) System. JPE 1987;8:431-7. doi:10.1007/BF02893152.

[58] El-Eskandarany MS. Mechanical alloying: Nanotechnology, Materials Science and Powder Metallurgy. Elsevier; 2015.

[59] Goldstein J. Scanning electron microscopy and x-ray microanalysis. Kluwer Academic/Plenum Publishers; 2003.

[60] Gennari FC, Castro FJ, Urretavizcaya G. Hydrogen desorption behavior from magnesium hydrides synthesized by reactive mechanical alloying. J Alloys Compd 2001;321:46-53. doi:10.1016/S0925-8388(00)01460-2.

[61] Rašković-Lovre Ž, Kurko S, Ivanović N, Fernández JF, Ares J-R, Šturm S, et al. Insitu desorption of magnesium hydride irradiated and non-irradiated thin films: Relation 
to optical properties. J Alloys Compd 2017;695:2381-8.

doi:10.1016/j.jallcom.2016.11.128.

[62] Leardini F, Ares JR, Bodega J, Fernández JF, Ferrer IJ, Sánchez C. Reaction pathways for hydrogen desorption from magnesium hydride/hydroxide composites: Bulk and interface effects. Phys Chem Chem Phys 2010;12:572-7. doi:10.1039/b912964b.

[63] Barkhordarian G, Klassen T, Bormann R. Kinetic investigation of the effect of milling time on the hydrogen sorption reaction of magnesium catalyzed with different $\mathrm{Nb}_{2} \mathrm{O}_{5}$ contents. J Alloys Compd 2006;407:249-55. doi:10.1016/j.jallcom.2005.05.037.

[64] Gulicovski J, Rašković-Lovre Ž, Kurko S, Vujasin R, Jovanović Z, Matović L, et al. Influence of vacant $\mathrm{CeO}_{2}$ nanostructured ceramics on $\mathrm{MgH}_{2}$ hydrogen desorption properties. Ceram Int 2012;38:1181-6. doi:10.1016/j.ceramint.2011.08.047.

[65] Bassetti A, Bonetti E, Pasquini L, Montone A, Grbovic J, Antisari MV. Hydrogen desorption from ball milled $\mathrm{MgH}_{2}$ catalyzed with Fe. Eur Phys J B 2005;43:19-27. doi:10.1140/epjb/e2005-00023-9.

[66] Matović L, Kurko S, Rašković-Lovre Ž, Vujasin R, Milanović I, Milošević S, et al. Assessment of changes in desorption mechanism of $\mathrm{MgH}_{2}$ after ion bombardment induced destabilization. Int J Hydrogen Energy 2012;37:6727-32.

doi:10.1016/j.ijhydene.2012.01.084.

[67] Luo Y, Wang P, Ma LP, Cheng HM. Hydrogen sorption kinetics of $\mathrm{MgH}_{2}$ catalyzed with $\mathrm{NbF}_{5}$. J Alloys Compd 2008;453:138-42. doi:10.1016/j.jallcom.2006.11.113.

[68] Chen G, Zhang Y, Chen J, Guo X, Zhu Y, Li L. Enhancing hydrogen storage performances of $\mathrm{MgH}_{2}$ by Ni nano-particles over mesoporous carbon CMK-3. Nanotechnology 2018;29. doi:10.1088/1361-6528/aabcf3.

[69] Barkhordarian G, Klassen T, Bormann RU. Effect of $\mathrm{Nb}_{2} \mathrm{O}_{5}$ content on hydrogen reaction kinetics of Mg. J Alloys Compd 2004;364:242-6. doi:10.1016/S09258388(03)00530-9.

[70] Polanski M, Bystrzycki J. Comparative studies of the influence of different nano-sized metal oxides on the hydrogen sorption properties of magnesium hydride. J Alloys Compd 2009;486:697-701. doi:10.1016/j.jallcom.2009.07.042.

[71] Li P, Wan Q, Li Z, Zhai F, Li Y, Cui L, et al. $\mathrm{MgH}_{2}$ dehydrogenation properties improved by $\mathrm{MnFe}_{2} \mathrm{O}_{4}$ nanoparticles. J Power Sources 2013;239:201-6. doi:10.1016/j.jpowsour.2013.03.096.

[72] Croston DL, Grant DM, Walker GS. The catalytic effect of titanium oxide based additives on the dehydrogenation and hydrogenation of milled $\mathrm{MgH}_{2}$. J Alloys Compd 2010;492:251-8. doi:10.1016/j.jallcom.2009.10.199.

[73] Pelletier JF, Huot J, Sutton M, Schulz R, Sandy AR, Lurio LB, et al. Hydrogen desorption mechanism in $\mathrm{MgH}_{2}-\mathrm{Nb}$ nanocomposites. Phys Rev B 2002;63:1-4. doi:10.1103/physrevb.63.052103.

[74] Ares JR, Aguey-Zinsou KF, Klassen T, Bormann R. Influence of impurities on the milling process of $\mathrm{MgH}_{2}$. J Alloys Compd 2007;434-435:729-33.

doi:10.1016/j.jallcom.2006.08.132. 
[75] Huot J, Pelletier JF, Liang G, Sutton M, Schulz R. Structure of nanocomposite metal hydrides. J Alloys Compd 2002;330-332:727-31. doi:10.1016/S0925-8388(01)016620 .

[76] Gattia DM, Todini E, Aurora A, Pilloni L, Montone A, Antisari MV, et al. Microstructural and Kinetic Investigation of Hydrogen Sorption Reaction of $\mathrm{MgH}_{2} / \mathrm{Nb}_{2} \mathrm{O}_{5}$ Nanopowders. Mater Manuf Process 2009;24:1058-63.

doi:10.1080/10426910903022361. 